\title{
VISÕES DE CURITIBA EM CENA
}

\author{
Marta Morais da Costa*
}

\section{A}

s pesquisas a respeito do teatro escrito e encenado em Curitiba serviram de base para vários ensaios meus ${ }^{1}$ e produziram um material muito rico, possibilitando sempre abordagens diferentes e produtivas. O presente estudo está apoiado em uma dramaturgia majoritariamente inédita em livro mas encenada, muitas vezes com sucesso.

Servem de sustentáculo a este ensaio duas questões básicas: pode-se inferir um quadro suficientemente nítido de diferenças e semelhanças entre as peças que têm Curitiba como cenário e assunto? Que espécie de cidade elas descrevem?

É imediata a resposta para a primeira pergunta. Há grande diversidade de perspectivas e, conseqüentemente, de visões da cidade nos textos teatrais. Da Curitiba provinciana, imatura capital, passando pela metrópole civilizada, da

* Universidade Federal do Paraná e Pontifícia Universidade Católica do Paraná.

1 Cf. PALCO público em Curitiba no inf́cio do século. In: Tradição/Contradiçāo. Curitiba: Minc/SECE, 1986; Verbetes sobre teatro em Dicionário histórico e biográfico do Paraná. Curitiba: BANESTADO/Livraria do Chain, 1991; CURITIBA, teatro e euforia. Revista Letras, Curitiba, n. 38, p. 94-101, 1989/1990; Em busca de um teatro perdido. Nicolau, Curitiba, Secretaria do Estado da Cultura, v. 13, n. 2, 19 jul.1988; PLANÁLTICAS histórias de amor: duas peças de Alcides Munhoz. In: SEMINÁRIO DO CENTRO DE ESTUDOS LINGǗ́STICOS E LITERÁRIOS DO PARANÁ (8.: 1995: Umuarama). Anais... Umuarama: UNIPAR, 1995. O TEATRO em Curitiba no período de 1961 a 1970 - I e II. Revista Letras, Curitiba, n. 4445, 1995-1996. Além de teses de doutorado e de professor titular da autora. 
crítica demolidora ao entusiasmo juvenil, até atingir o protótipo da capital ecológica, muitos retratos e painéis foram sendo pintados dramaturgicamente.

Curitiba como cidade vista do palco irá se desenhando pouco a pouco à medida que se expõe o desenrolar histórico de palcos, pessoas e projetos teatrais que, em sua natural sequiência, formaram públicos e locais.

O primeiro palco da cidade situou-se, em construção provisória, num terreno pertencente ao padre João de Abreu Sottomaior. O segundo, numa antiga oficina de ferrar animais. Este passado nada abonador não impediu a encenação de peças eruditas do repertório da época, batizando com paradoxos a recém-nascida atividade teatral. Trabalho braçal e refinamento caminharam enlaçados pelas ruas de lama, posteriormente calçadas, hoje estruturais e rápidas avenidas.

Assim como a cidade se amplia e moderniza, também cresce o movimento teatral, sempre assentado nos binômios trabalho-refinamento, suorarte.

Se, visto dos bastidores, o teatro curitibano revela-se antitético, não menos contraditório ele se apresenta na platéia. Públicos diferentes saúdam ou renegam os espetáculos, construindo paulatinamente o mito de público exigente, de cidade teste para os espetáculos forasteiros.

O nascimento do teatro na cidade não ocorreu, porém, de maneira diferente daquela de outras cidades brasileiras de igual porte. Os raros palcos serviram para esporádicas companhias visitantes - geralmente mambembes e de qualidade abaixo da regular - durante todo o século XIX e a primeira metade do século seguinte.

A dramaturgia local, por sua vez, esboça seus primeiros movimentos ao final do século. A cidade como assunto ou cenário convive com outros textos em que há total vagueza quanto à localização do conflito dramático. Nestor de Castro escreve em 1897 a peça $A$ greve, que tem por assunto as reivindicações trabalhistas dos operários curitibanos. Infelizmente, esse texto pionciro ainda não foi localizado.

Curitiba aparece com freqüência no início do século $\mathrm{XX}$ em peças teatrais conhecidas como revistas. A revista é uma forma dramática que alia os acontecimentos, modismos e costumes à sátira política e social numa espécie de "espelho do cotidiano". A música, as canções, o cômico, as coristas, o cenário e o figurino bem cuidados constituem os ingredientes indispensáveis a uma boa revista. Seu sucesso no início do século em Curitiba era assegurado por companhias itinerantes e por grupos amadores locais. A montagem dos espetáculos de revista por elencos mambembes incentivou os autores paranaenses, que fizeram da cidade - seus espaços e habitantes - o enredo de suas peças. 
Esses textos, desaparecidos em sua maior parte, tinham a característica do efêmero, pois os fatos retratados, muito datados, acabavam perdendo sua importância e sentido com o passar dos anos. Mas nos fragmentos que sobreviveram ficaram registradas as primeiras imagens de Curitiba apresentadas sobre os palcos. Neles é possível constatar a convivência da crítica e da exaltação à cidade, fruto da observação da realidade e do desejo de construir a utopia de um espaço ideal, harmonioso, edênico.

Entre as primeiras revistas registradas em documentos, e que tiveram Curitiba como motivo, encontram-se Colcha de retalhos, de Serafim França, estreada em 22 de julho de 1906; Curitiba em cinematógrafo, de Serafim França e José Gelbecke, que estreou em 22 de novembro de 1908; Do Rio Grande a Curitiba - o meio, de Dolival Moura e José Gelbecke, que estreou em 16 de dezembro de 1911; Alô! Alô, Curitiba!, de Rodrigo Júnior e Jean Rhine, cuja primeira apresentação data de 15 de novembro de 1912; A crise, de Serafim França e Francisco Leite, apresentada em 3 de junho de 1915, e $O$ diabo em Curitiba, de Francisco Leite, com estréia em 13 de dezembro de $1915 .^{2}$

E quem julga que a pequena Curitiba se contentava, nos primeiros anos do século XX, em assistir ao desfile de cavaleiros, carruagens e bondes puxados a burro pelas ruas enlameadas ou mal pavimentadas, engana-se. $O$ circo, a tourada, o teatro, os saraus e os bailes movimentavam a cidade com inesperada freqüência. Essa agitação ganhou, a partir de 1907, o impulso modernizador do cinema. Em 1901, o Circo Peri se deu ao luxo de assoalhar todo o pavilhão para receber platéias de até 2 mil pessoas, ansiosas por assistir a pantomimas aquáticas representadas na arena inundada por 80 mil litros de água! Em 1901 ainda, uma pequena companhia infantil espanhola sublevou os espectadores com o drama anticlerical Electra, de Peres Galdós, originando pequeno tumulto que resultou em vidraças quebradas na casa paroquial. Não se omitiram os jornais curitibanos, descrevendo ou tomando partido no episódio. A imprensa, saliente-se, exerceu importante papel no registro de fatos e na divulgação de idéias a respeito do teatro, bem como alimentou e sustentou a crítica teatral militante.

Considerando a diminuta população da cidade que, em 1900, chegava a 30 mil habitantes e não ultrapassava os $50 \mathrm{mil} \mathrm{dez} \mathrm{anos} \mathrm{depois,} \mathrm{é} \mathrm{admirável}$ a movimentação constante de companhias estrangeiras nos anos iniciais do século. O sucesso maior do período que antecedeu a Primeira Guerra Mundial deve ser creditado à opereta vienense que, trazida por companhias alemãs,

2 COSTA, Marta Morais da. Teatro em papel jornal. São Paulo, 1987. Tese (Doutorado) - FFLCH, Universidade de Sāo Paulo. p. 125-135. 
lotava o Teatro Hauer e o Teatro Guaíra em espetáculos de luxo e competência. Nenhuma delas, porém, obteve o êxito da Companhia Mexicana de Esperanza Íris em 1919. Subsidiada pela prefeitura e pelo governo do Estado, dominou como um furacão os corações dos amantes de teatro e as gordas algibeiras da burguesia curitibana. Em troca de espetáculos de alto luxo e esfuziante alegria, cobrou os ingressos mais caros que a sociedade local já consentira em pagar. Sua passagem pela cidade inaugurou uma sequiência rápida e marcante de grandes companhias teatrais do Brasil e do exterior. Palcos e jornais não encontravam tempo para repouso e retomada de forças. A roda-viva dos espetáculos e da crítica era incrementada ainda mais por apresentações de grupos amadores. Dramaturgos curitibanos - bissextos ou de produção contínua alinhavam-se na vanguarda do movimento de afirmação do teatro local: José Cadilhe, Ernesto de Oliveira, Paulo Assumpção, Alcides Munhoz, Ernesto Niemeyer, Jaime Ballão Júnior, Ernesto Merlin, José Buzetti Mori, Benedito Nicolau dos Santos e outros mais.

O período pós-guerra assistiu ao crescimento do número de companhias nacionais e ao aperfeiçoamento técnico e dramatúrgico dos espetáculos. Essa efervescência cultural e teatral não representou, porém, modernização, como acontecia na Europa. O teatro brasileiro continuava marcando passo na revista de atualidades, na comédia de costumes e no drama psicológico novecentista de estilo francês. Num país de tradição teatral pobre como o nosso, a década de 20 propiciou, contudo, um momento de afirmação do teatro nacional. Os festejos do centenário da independência política ensejaram obras patrióticas - passageiras e ufanistas - e favoreceram a reflexão a respeito de nosso atraso cultural. $\mathrm{O}$ teatro demorou a encontrar um caminho próprio em razão de sua essência peculiar: como arte coletiva necessita do desenvolvimento harmônico de todos os seus componentes para que possa alcançar um progresso definitivo. Dramaturgia, encenação e interpretação cênica precisam somar-se a um público igualmente progressista para determinar um momento marcante na história do espetáculo.

No final da década de 20, a cidade vive o apogeu da experiência coletiva e integradora de várias linguagens artísticas da Sociedade Teatral Renascença, sob a presidência de Salvador de Ferrante.

É desse período vibrante que surgem os primeiros textos que tomam Curitiba como assunto. O predomínio das comédias na dramaturgia local forma dramática que tem como princípio organizador o cotidiano e a atualidade - pode fazer supor que Curitiba tenha se tornado com frequiência o cenário teatral predileto dos dramaturgos. $\mathrm{Na}$ verdade, os textos da então chamada alta comédia procuravam localizar a ação em salas e casa pouco definidas 
espacialmente. Daí a importância de peças como $O$ vigilado (1921), Castor e Pólux (1922) e Flor do campo (1922), de Alcides Munhoz, ${ }^{3}$ que escapam porta a fora para falar de espaços mais amplos. Na primeira, Curitiba avulta como espaço com personalidade: são os bailes do Clube Curitibano, são as fábricas de moagem da erva-mate que circundam a cidade, é a referência aos hábitos e locais de diversão, como os cinemas e teatros. A cidade ganha ares civilizados, onde as personagens, refinadas, circulam com liberdade e onde atos desabonadores não conseguem êxito. Nada pode toldar essa imagem elevada, construída para servir de suporte aos amores e pequenos dissabores de burgueses dedicados a bailes, partidas de tênis, conversas de salão e intrigas amorosas.

Em Castor e Pólux, o drama da indecisão amorosa da donzela por dois rapazes igualmente sedutores se resolve na romântica igrejinha da Água Verde, de cujas janelas se pode apreciar a turística e tradicional paisagem com pinheiros. $\mathrm{O}$ bairro aristocrático do Batel, onde mora a família da protagonista, e o da Água Verde constituem tão-somente o cenário indispensável para o desenrolar do drama amoroso de uma moça indecisa. Mas o olhar do dramaturgo não se detém com atenção sobre o espaço urbano e seus tipos característicos. A peça centra-se mais no drama interior da jovem Ema.

Flor do campo apresenta um drama espacial: a jovem Olívia tem que escolher entre ficar em Guarapuava como esposa de um fazendeiro e industrial ou vir a Curitiba para conviver com a alta sociedade e, talvez, casar-se com um burguês urbano. Na peça, Curitiba representa a capital da ambição, da maledicência, dos interesses escusos e da hipocrisia, distante da civilizada, bela e hospitaleira cidade das peças anteriores. Olívia prefere ser a flor do campo.

Essa visão crítica da capital tem função, acima de tudo, ideológica: a de construir uma oposição - um tanto romântica e desatualizada - entre campo e cidade. $\mathrm{O}$ afastamento do presente de modernização, vivido pelos anos 20 , cria uma defasagem temporal que acaba numa estereotipia de situações e personagens, redundando na má qualidade dramatúrgica da peça.

O texto foi lido na noite de 19 de dezembro de 1921 , no Clube Cassino Curitibano, como parte dos festejos do $68 .^{\circ}$ aniversário da emancipação política do Paraná. O embate entre as regiões de Guarapuava e Curitiba teve a primeira como vencedora e o Paraná teve motivos para orgulhar-se do interior do Estado e de seus habitantes de inquebrantáveis virtudes: a simplicidade, o amor ao trabalho, a pureza de intenções, a iniciativa e a fé no progresso. Todas enaltecidas

3 MUNHOZ, Alcides. Comedia paranaense (l." série). Curitiba: [s.n.], 1921. p. 17-213. 
em diálogos explícitos de tom moralizador.

Esta mesma visão opositiva se manifesta em Coisas da moda, de Castela $\mathrm{Braz}^{4}$ (1923), em que a crítica aos modismos e à futilidade converte-se em defesa de virtudes conservadoras e de espaços idealizados e em extinção, num retrocesso face às conquistas da civilização e da arte que o autor, poeta modernista, divulga como literato e nega como dramaturgo. A peça vale-se dos diálogos para defender, em tom moralizador, os costumes antigos, atribuindo ao presente defeitos insuperáveis. Estende a oposição entre a roça e a cidade para conflitos entre o interior e a capital, a virtude e a perdição, o permanente e o modismo, o essencial e o aparente, em que Curitiba estará associada aos deploráveis segundos termos dessas antíteses.

A peça confirma desse modo a concepção vigente na época em Curitiba de que o teatro deveria ser uma tribuna em defesa dos bons costumes, esquecendo de que ele é, acima de tudo, uma linguagem específica de criação artística, em que os valores ideológicos só se mantêm se a verdade estética permanecer.

Outro bairro da cidade serve de local bucólico e motivador para os duelos de palavras e atitudes dos enamorados em disputa pelo olhar da amada. $\mathrm{O}$ Cajuru serve de cenário à história de Marumby, de Benedito Nicolau dos Santos (1928), ${ }^{5}$ como a profetizar com suas paisagens abertas e floridas a proximidade do atual Jardim Botânico.

Trata-se de uma "opereta de costumes paranaenses", na classificação de seu autor. Foi representada no Teatro Palácio em 1928, com música e regência do próprio dramaturgo. O teatro brasileiro vivia, na época, mais uma de suas fases de nacionalização: do palco, da dramaturgia, da dicção dos atores. Buscavam-se os motivos e os cenários brasileiros, como se pode verificar na obra de Oduvaldo Vianna. Em Curitiba, os jornais estimulavam a criação de textos e espetáculos locais, com intensa produção de artigos e ampla cobertura publicitária. A estréia de Marumby foi precedida de contínuas notícias, exaltando a escolha regional de cenário e personagens.

A ação transcorre em Curitiba mas amplia o cenário até Morretes, com o pico do Marumbi, a cachaça morreteana e o fandango. A história sentimental que norteia a ação dramática se apóia em clichês da época: não faltam duelos entre rivais no amor de uma jovem desprotegida e virtuosa, nem o confronto entre o rico industrial estrangeiro e o inculto sertanejo - violento e

4 BRAZ, Castella. Coisas da moda: peça de costumes locais em 2 actos para ser lida. Curitiba: [s.n.], 1923.

5 SANTOS, Benedito Nicolau dos. Marumby: opereta de costumes paranaenses em 3 atos. s.i.e. 
beberrão. Este, auxiliado pelo cunhado, um descendente da velha raça tindiqüerana, salva a donzela das mãos do industrial e a conquista para si. Para completar a reconstrução da realidade vista pelos olhos de Benedito Nicolau dos Santos, o primeiro ato encerra-se com a neve cobrindo a cidade.

Novamente a cidade se faz palco estereotipado de histórias amorosas que também repetem encontros e desencontros sempre os mesmos. São a neblina, o frio e os estudantes que preenchem a ação dramática com episódios reprodutores de clichês dramáticos da época. E pairando em feitio paranista a dominar toda a paisagem está o Marumbi, símbolo do elevado espírito dos curitibanos. Aliás, frequientemente, Curitiba e o Paraná se igualam, a lembrar que até 1930 o Estado se estendia de Paranaguá a Guarapuava, tão-somente. O restante do território era terra virgem, desconhecida, inexplorada, adormecida.

A morte de Salvador de Ferrante, em 1935, e o paulatino abandono do Teatro Guaíra, dois baluartes de defesa do teatro curitibano, foram aos poucos silenciando os dramaturgos da cidade, sem espaço de divulgação, sem empenho de grupos amadores. É notável a comprovação no noticiário local do desaparecimento de grupos e autores simultaneamente à morte do edifício do teatro municipal. Aos poucos, a cada parede derrubada, o movimento teatral parecia refluir. $O$ teatro, emblema da cidade, acabou sendo destruído pelo tempo e pelos homens. A demolição se prolongou de 1935 a 1947. A não ser pela dedicação de Aristides Teixeira, levando espetáculos em espaços alternativos, e a criação do Teatro do Estudante do Paraná, em 1948, sob a direção de Armando Maranhão. Novo alento se dará a partir dos anos 50, quando outra efervescência amadorística, crítica e dramatúrgica se revela na exploração e multiplicação de espaços teatrais. Renasce o Guaíra, vivem o Teatro de Bolso, o auditório do Colégio Estadual do Paraná, as associações e sociedades. Grupos se multiplicam, nasce o profissional de teatro, cria-se a Escola de Arte Dramática do SESI. Escrevem para teatro Eddy Franciosi, Cícero Camargo de Oliveira e Didi Fonseca, entre outros. Em seus textos, porém, a cidade não está presente nem como cenário.

Em 1973, no Teatro Paiol, é montada a peça Minha cidade sem portas, de Aderbal Fortes de Sá, com música de Paulo Vítola. Curitiba volta a ser neste momento o paraíso terreal em que todas as raças e todas as pessoas encontram abrigo e solidariedade. Como a buscar raízes e luzes, as peças do período traçam necessariamente a história do surgimento da cidade, recheando os diálogos com índios, ouro, Atuba, Eleodoro, Pinhais, pelourinhos e intrigas entre Curitiba e Paranaguá. Somente após o pretérito tempo histórico decorrido, desfilam pelo palco os tipos e acontecimentos da cidade do presente. 
Dos textos que têm Curitiba como assunto, este é um dos mais importantes, por variadas razões. Em primeiro lugar, por tratar a cidade com o respeito e o conhecimento do historiador. A peça compõe-se pela justaposição de quadros históricos alinhados pelo critério cronológico e evolutivo na firme intenção de adensar a imagem da capital, conferindo-lhe o aval das referências factuais. Em segundo lugar, porque concebe a encenação nos moldes do teatro mais comunicativo, nacional e popular da época: o teatro do Grupo Arena de São Paulo. Encenada em 1973 no Teatro Paiol, a peça tem a indicação do palco circular; o cenário e o figurino são despojados e sem marcas temporais; a música integra-se ao tex to e lhe dá suporte; e a interpretação dos atores se faz pelo método Coringa, teorizado e aplicado por Augusto Boal e Gianfrancesco Guarnieri no Arena. A sequêencia dos momentos históricos (a fundação da cidade, o ciclo do ouro, o tropeirismo, os ciclos do mate e da madeira, o período entre-séculos, a Revolução de 30 e os sucessivos governadores) é acompanhada de contínua atualização, trazendo ao presente dos espectadores uma interpretação do passado. Em terceiro lugar, a presença do cômico e das canções dita o ritmo da peça, amenizando a aridez e a lentidão dos quadros históricos, num contraponto produtivo que solicita a cumplicidade do espectador.

Regendo esta multiplicidade está a intenção de construir uma cidade sem portas, em que os defeitos se amenizem e as boas qualidades se reforcem; atitude que contribui para a descoberta e valorização do espaço urbano. $O$ objetivo de exaltar a cidade se incluía no projeto cultural dos anos 70 , de que a peça é um dos exemplos mais evidentes.

A cidade que apareceu até esta data em revistas e comédias se apresenta agora numa forma épico-histórica em que o humor apenas tempera a seriedade da informação. O período limitado pelos anos 70 e 80 decorreu sob a opressão ditatorial e a instabilidade e violência da censura. A realidade metaforiza-se para poder existir no palco. A personagem e suas falas eram decifradas por códigos paralelos. $O$ teatro sobrevivia precariamente, roubado em sua essência libertária. A mordaça censorial silencia o deboche da revista. Ocupam o seu lugar os musicais histórico-ufanistas que visavam a recuperar, em forma dramática, a imagem ordenada e documental do passado, procurando recompor um esfacelamento crítico divulgado pela comédia e pela revista. Em Curitiba, são montadas as peças Minha cidade sem portas (1973) e Terra de todas as gentes (1974), ambas de Aderbal Fortes de Sá com música de Paulo Vítola, e ó Curitiba, nossa tribo, salve! salve!, de Marinho Galera e Paulo Vítola, de 1980. Estes espetáculos didatizam a cidade e seus habitantes. Preferem o mural ao retrato, o épico ao satírico, o coletivo tribal ao tipo característico. $\mathrm{O}$ atrativo maior do espetáculo é a música, cuja letra - misto de história e lirismo - 
demonstra o predomínio do pessoal e do poético. Funcionam essas peças como tentativas de dar à cidade um respaldo histórico e identidade. Num período de campanhas cívicas e patrióticas, essas peças revelam-se adequadas.

Em 12 de dezembro de 1974 havia sido inaugurado, em grande estilo, o Auditório Bento Munhoz da Rocha Neto, o Guairão. Noite de festa que contou com a presença do então presidente da República, Ernesto Geisel. No palco, foi representada Terra de todas as gentes, a saga das famílias paranaenses, de raízes tradicionais ou provindas de outras terras, embaladas pelo sonho de uma vida melhor divulgado pelo programa de colonização implantado ao final do século XIX no Brasil. Contavam-se ali, em forma teatral, os conflitos causados pelas difíceis relações entre diferentes povos e culturas.

O sonho de uma terra acolhedora e pacífica norteia as intenções desse musical em que a miscigenação racial dirige os acontecimentos. Nem mesmo Antônio Ernesto Portugal, descendente dos fundadores de Curitiba, consegue resistir à força da integração social dos imigrantes que povoam o Paraná; ainda mais com uma família de sete filhas casadouras... O desejo de Antônio Ernesto é casá-las com os filhos das tradicionais famílias de Curitiba. O sonho das moças, porém, é casar por amor. Assim, passam a integrar a família Portugal alemães, poloneses, italianos, holandeses, árabes e japoneses, todos escolhidos à revelia do patriarca.

O texto representado anunciava em seu título a intenção de exaltar. As circunstâncias históricas do momento nacional justificavam a saga com final feliz: o novo teatro, o prestígio oficial das autoridades presentes, a valorização do teatro local e de seus artistas, a encenação do texto de um dramaturgo paranaense e a intenção de dar por concluído o grande projeto modernizador das "Obras do Centenário" de Bento Munhoz da Rocha, de que o Teatro Guaira era um dos ícones. Toda essa magnitude cabia dentro do projeto maior, o do milagre brasileiro, patrocinado pelo governo militar.

O momento histórico comportava, porém, a sua contradição. No mesmo ano de 1974 vai surgir da própria história da cidade o herói teatral revolucionário. É o caso de Maria Bueno, de Oraci Gemba: ${ }^{6}$ a doméstica rebelde convertida em protótipo libertário e de afirmação feminina. $O$ objeto de veneração é lido no tempo de sua dramatização como a reencarnação de Maria Goretti, mártir do desejo obscuro dos homens, e de Joana d'Arc, guerreira em luta contra a indiferença social. Seu discurso pode ser lido, portanto, fora do registro religioso: ela é a mulher em luta contra a cidade maldizente; ela é a 
heroína política na batalha contra a urbe corrompida e opressora; ela é a mártir de um ideal de liberdade e autodeterminação.

Ao início da peça, Curitiba é alvo do desejo de ascensão pessoal de Maria Bueno. Morretes, onde nasceu, e Campo Largo, onde foi educada pelas irmãs marcelinas, representam o passado que apodreceu. Na capital é rodeada por cidadãos hipócritas e preconceituosos. Da cidade do final do século XIX, época em que transcorreram os fatos narrados, há apenas a referência espacial à Praça Tiradentes. A cidade é antes representada por seus habitantes, verdadeira encarnação do Mal, de quem Maria Bueno se pretende adversária exclusiva e fervorosa. Nem pitoresca, nem hospitaleira, nem heróica: a cidade é, acima de tudo, o reduto da maldade. Maria Bueno, desafiando-a e combatendo-a, transformar-se-á em santa. Cidade com portas e mordaça, a Curitiba desse texto é hipocrisia, intolerância, martírio.

O espetáculo que reabriu o histórico Teatro de Bolso, na Praça Rui Barbosa em 30 de março de 1980 foi Ó Curitiba, nossa tribo, salve! salve!, de Marinho Galera e Paulo Vítola, ${ }^{7}$ que reuniram história, crítica e poesia numa peça que conta e canta a existência da cidade, de sua fundação à data de estréia. Fruto de pesquisa histórica atenta, o texto alia o documentário ao poético, o espaço e a gente à sua história, numa perspectiva dinâmica dos acontecimentos. A peça, em suas canções, revela-se um longo e criativo poema de amor à cidade de várias facetas e etnias, de várias qualidades e defeitos, de várias histórias e de uma única: a do próprio texto, espelho dos valores de Vítola e Marinho. Uma cidade amada e mestiça, em que a moça graciosa se identifica com a "polaquinha de cabelo pixaim". O contraponto entre o texto histórico e as canções faz alternar diferentes perspectivas textuais. Enquanto a história representa um saber coletivo e racional, as canções se constituem em expressão do enfoque pessoal e lírico: realizam uma leitura sincrônica e valorativa, imprimindo o selo da atualidade na mensagem diacrônica.

Nos dois textos de Laerte Ortega ${ }^{8}$ - O funeral da rua 37 (1976) e Esmeralda Bandeira (1978) - a cidade transforma-se em cenário de lutas sociais. Desloca-se o foco da narrativa dramática do centro para a periferia da cidade. Troca-se a abordagem pitoresco-turística pela denúncia do conflito entre os mais fortes econômica e socialmente e os desprotegidos. A luta cotidiana das personagens pela sobrevivência em fábricas, nas ruas, nas escolas ou dentro de casa resulta em derrotas contínuas. Dilacerando-se em disputas sentimentais,

7 GALERA, Marinho; VíTOLA, Paulo. ó Curitiba, nossa tribo, salve! salve! Curitiba, 1980. Mimeog.

8 ORTEGA, Laerte. Funeral da rua 37. Curitiba, 1976. Esmeralda Bandeira. Curitiba, 1978. Mimeog. 
ocasionadas freqüientemente pela pobreza, esfacelam-se as famílias. Dominados pelos detentores do capital, os moradores da Rua 37 são despejados de suas casas, sofrendo sob o distante e frio brilho da lua. Migrando para um novo local, essa gente sem esperança vê sua história prolongada num segundo texto do autor, Esmeralda Bandeira. Ocupando agora o Bairro da Saúva, os moradores assumem às claras a luta política e a peça se converte num texto de engajamento em favor dos marginalizados e oprimidos, abandonando mais ainda a localização geográfica referencial, construindo um cenário vago, que pode ser um lugar qualquer.

Curitiba não tem nessas duas peças os encantos de cidade sorriso ou de capital ecológica. É a urbe-fonte-de-privilégios que empurra para limites cada vez mais distantes e miseráveis a população desamparada. Em seus espaços centrais habitam apenas os detentores do poder e do capital. Essa face conflituosa e madrasta raras vezes esteve presente nos textos que tomaram a capital do Paraná como assunto e cenário.

Político também, embora em tom mesclado de seriedade e humor, é o par Curitiba, velha de guerra (1978) e Dos seios desta mäe gentil (1980), ${ }^{9}$ criações coletivas do Grupo Teatral Prisma, dirigido por Antônio Carlos Kraide. Em razão de sua forma de composição coletiva, há nessas peças uma disparidade de estilos dramatúrgicos. Une os episódios, porém, o desejo de retratar qualidades e defeitos da cidade e dos curitibanos. A repercussão positiva de Curitiba, velha de guerra junto ao público originou a continuidade em Dos seios desta mãe gentil. $\mathrm{O}$ tom de deboche e de crítica em episódios retratando hábitos da alta sociedade, como os desfiles de modas e de misses (Dos seios...) alternavase com a seriedade dos dramas individuais (Curitiba, velha...) . Nesta última, a idéia de ligar os episódios independentes pela localização nos bares da cidade resultou em maior unidade do texto, o que não ocorreu na segunda, peça dramaturgicamente descosida e irregular. Nelas, o pitoresco e o turístico são desmascarados intencionalmente pela ironia e o humor. Permanece, entretanto, uma profunda ligação afetiva com a cidade, seus defeitos e qualidades, expressa até nos títulos - velha de guerra e mãe gentil. As personagens mostram a solidão, a hipocondria, os desajustes emocionais, as relações de servidão consentida e os encantos do poder. São os filhos dessa mãe impiedosa, amadurecidos e sem ilusões, que mostram a cidade através de uma perspectiva distanciada e crítica: a cidade só ri quando dói.

Em Dos seios desta mãe gentil, as cenas independentes mostram donas

9 GRUPO TEATRAL PRISMA. Curitiba, velha de guerra. Curitiba, 1978; Dos seios desta mãe gentil. Curitiba, 1980. Mimeog. 
de pensão, matriarcas, jovens prostitutas, artistas, mágicos, dentistas, taxistas e funcionários públicos. Cruzam-se em pensões, consultórios, residências ou na rua. Desvestem-se interiormente, vivendo dramas de solidão, homossexualismo, ambição e guerras familiares. A cidade aparece claramente delineada na referência a seus espaços públicos (Avenida das Torres, Bigorrilho, Rua Jacarezinho, Teatro Guaíra, Barreirinha e outros), a seus acontecimentos (a invasão da Reitoria da Universidade Federal do Paraná, os fatos políticos, o taxista parteiro) e a seus tipos humanos (a polaca, a dona de pensão, o estudante). A peça retoma, em termos de estruturas dramáticas, o esquema da revista musical, com quadros justapostos e a intenção de construir um painel descritivo da cidade e de seus habitantes.

O mesmo espírito revisteiro está em Obrigado, Curitiba, de Otelo Queirolo, que foi apresentado em palcos e auditórios da cidade a partir de 1981 pelo Grupo de Teatro Popular, dirigido por Juve Garcia. Fatos pertinentes à cidade ou a acontecimentos da realidade brasileira eram justapostos em esquetes cômicos, finalizados por uma apoteose à cidade. Sem texto definitivo, o espetáculo era antes um roteiro, aberto à inclusão de cenas novas e atualizadas.

Dois textos de Nelson Di Córdova, sem data precisa de composição - os acontecimentos neles narrados fazem supor a criação ao longo dos anos 80 tomam uma parte de Curitiba como cenário e assunto: Gilda da Boca Maldita e Maldita Boca Maldita. ${ }^{10}$ Os títulos esclarecem o local e até o tom e protagonista. No primeiro texto, o dramaturgo biografa o travesti Gilda em sua trajetória rumo à marginalização, ao abandono e à morte. É a história de um ser humano que decai por amor. A abordagem lírica e idealizada privilegia a perspectiva de Gilda, colocando-a sempre em confronto com uma sociedade mesquinha e preconceituosa. Embora tenha aparecido em outras peças como citação ou exemplaridade, é nesta peça que a personagem ganha o centro do palco e da ação. A peça serve-se do biográfico e referencial para construir um documento-denúncia dos preconceitos sociais e do tratamento desumano dado aos homossexuais. O homossexualismo é encarado sob a ótica do amor e da doação. O centro dramático pertence a Gilda que, num monólogo, expõe sua biografia. Ao final, o ator-intérprete presta uma homenagem apoteótica ao travesti morto, lendo um "documento sinopse".

Maldita Boca Maldita é uma peça enciclopédica sobre a cidade. Não porque se trate de um texto exaustivo ou científico. Enciclopédica por tentar

10 CÓRDOVA, Nelson di. Gilda da Boca Maldita. Maldita Boca Maldita. Curitiba, [198?]. Mimeog. 
abranger em uma dezena de páginas a multiplicidade dos tipos sociais e dos acontecimentos contemporâneos à peça e que fazem a história da cidade. $O$ texto mantém uma tonalidade crítica que não perdoa a burguesia, nem a classe média, nem o proletariado. É impiedoso com artistas - principalmente de teatro-, políticos, empresários e religiosos. Termina, porém, exaltando a cidade. A fala final da peça representa uma visão lírica dos aspectos esquecidos e marginais da cidade; o tom se faz carinhoso e a exaltação permanece, independente dos resquícios de uma profunda tristeza e, até mesmo, de angústia. $O$ resultado final, contudo, é desanimador. A peça poderia denominar-se, como a de Serafim França, em 1906, Colcha de retalhos. Quase uma centena de personagens, com fala única, relampagueiam pelo palco e desaparecem. A tentativa de centralizar num único texto o polimorfismo urbano resultou frustrada.

Ampliando um pouco mais a geografia, ao retratar todo o percurso da Rua das Flores, Lineu Portela consegue maior unidade em Rua das Flores não é mais aquela ${ }^{11}$ (1986). Texto de lenta elaboração, iniciado em 1977, foi sendo amadurecido em seus episódios pela observação da realidade. $O$ resultado foi um painel de tipos e situações que constroem o dia-a-dia da cidade. $O$ fio narrativo é sustentado por um casal de norte-americanos, Lewis e Corina, que procuram conhecer os locais turísticos mas se defrontam com surpresas e desilusões: a rua para pedestres é invadida por veículos de carga, por homossexuais e trombadinhas, estudantes confusos e policiais preconceituosos, além de pedintes de todas as espécies. A intenção evidente é a de desmistificar a visão turística e burladora de uma cidade asséptica, harmoniosa e modelar.

O texto inicia com um discurso político idealizador e recheado de chavões a respeito da urbanização e do destino da Rua das Flores: ela está sendo entregue aos pedestres que transitarão alegres e descontraídos. Desmentindo essas palavras, sucedem-se cenas em que avultam os contrastes e os males de uma sociedade violenta, hipócrita e desumana. São tipos caricatos, e, por isso mesmo, cômicos: estudantes, travestis, boys, vendedores ambulantes, nordestinos, secretárias, funcionários públicos, prostitutas, policiais, atores, bailarinos e autoridades. Compõem a galeria de tipos que expõem as mais variadas situações, em cenas ou em alusões verbais. Contos do vigário, o jogo, os tóxicos, a sexualidade, o estelionato, os preconceitos, as frustrações, a maledicência, enfim, os vícios de qualquer agrupamento humano estão deslocados por este axis mundi que é a Rua das Flores. Lineu Portela nos apresenta com impiedade e humor essa metonímia da cidade.

11 PORTELA, Lineu. Rua das Flores nāo é mais aquela. Curitiba, 1986. Mimeog. 
Uma parcela da história do teatro na cidade está documentada em $O s$ trancetês do CPT, de Adriano Távora ${ }^{12}$ (1986). Nesta revista teatral o assunto é o Curso Permanente de Teatro da Fundação Teatro Guaíra, descrito em sua trajetória histórica. $\mathrm{O}$ autor apoiou seu texto em fatos e pessoas reais, procurando registrar em forma dramatúrgica os 26 anos de duração do curso. Predomina o tom saudosista e de homenagem às pessoas que fizeram a história do curso. A cidade é o pano de fundo dos acontecimentos, que são o interesse exclusivo da narrativa dramática.

Em 1985 saem publicadas duas peças da maior importância para a dramaturgia paranaense: A reputação do Quatro Bicos e $O$ Homo sensualis, ambas de Luiz Groff. ${ }^{13}$ A primeira delas cumpriu seis meses ininterruptos de temporada em 1982, fato incomum na cidade.

Curitiba faz-se representar metonimicamente pelo bordel Quatro Bicos. Freqüentam-no os diferentes tipos urbanos: o executivo, o delegado, o burguês. Em todos eles, o desejo de ocultar, sob a máscara do bom comportamento social, as pulsões sexuais. Ao ostentar a dupla moralidade, transformam-se em alvo fácil do discurso frio, irônico e humorístico do dramaturgo. Pressionadas pelo temor à polícia - protótipo inquisitorial dos tempos da censura e da perseguição política no Brasil - as personagens desnudam-se ante os olhos do público. Pobre sociedade curitibana: exposta sem piedade em sua fraca e forte gente, mostra com absoluta precisão as suas mazelas. $O$ humor cortante de Luiz Groff impede o riso da superioridade. Rimos das situações e personagens sobre o palco, mas sentimos interiormente o travo do reconhecimento de nossos próprios comportamentos ridículos. Rimos de nós mesmos. É o riso cruel resultante da consciência da nossa fraqueza.

O humor cáustico de Luiz Groff evita que as situações criadas desçam ao nível da grosseria ou da pornografia. O tom crítico e mordaz ao mesmo tempo em que faz rir revolve a ferida e provoca a dor. Esse texto de tratamento densamente teatral constitui uma das melhores peças a respeito de Curitiba. Desaparecem os aspectos turísticos e circunstanciais e avultam a análise e a crítica cruel do modo de ser curitibano. A reputação do Quatro Bicos representa, em versão teatral e humorística, o retrato de Curitiba com tintas de Dalton Trevisan. Há grande afinidade entre os dois criadores no que respeita aos valores e intenções expostos no texto. Cada um em seu gênero e estilo

12 TÁvORA, Adriano. Os Trancetês do CPT. Curitiba, 1986. Mimeog.

13 GROFF, Luiz. A reputação do Quatro Bicos \& outras reputą̧ōes. São Paulo: Massao Ohno, 1986. 
próprio aponta para a face oculta de uma cidade com muitas portas trancadas, com sótãos e porões.

Resta afirmar em A reputação do Quatro Bicos o texto à feição de Molière, em que o riso é uma forma de castigo à vaidade e à hipocrisia dos homens. De fato, esta comédia transcende os limites geográficos da cidade para se localizar no espaço mais movediço, porém mais profundo, da alma humana em seus subterfúgios e desvios, maneiras de fugir à realidade.

Igualmente desvendadora é a função do dramaturgo em $O$ Homo sensualis, monólogo de alta voltagem cômica e de grande riqueza de recursos teatrais. $\mathrm{O}$ homem diante da solidão tenta mascarar seu abandono construindo para si o disfarce de um atraente e irresistível conquistador. A sequiência das situações faz com que ele se descubra só, e traído. O riso amargo, oriundo da descoberta da traição, antes aflige do que purifica o espectador/leitor. Derrotado, o protagonista vinga-se da cidade e da vida. Não há como fugir à consciência dolorosa a que chegamos a respeito dos inúteis esforços do ser humano para atingir alguma grandeza, para sobrepor-se à realidade de sua solidão.

A reputação do Quatro Bicos e $O$ Homo sensualis constituem dois textos de acentuada teatralidade e apresentam uma visão verticalizada de Curitiba, despida de atributos pitorescos e glamourosos, para se ver transformada no espaço de confrontação do ser humano com suas verdades. A cidade ganha densidade nesses textos, tornando-se substantiva, indispensável. Nela vivem homens de complexo universo interior em choque frontal com sua impotência afetiva.

Em 29 de março de 1992, Curitiba ganhou, em sua data de aniversário, a leitura dramática de Curitiba, capital do freezer, de Geraldo Magela Cardoso. ${ }^{14}$ Nessa peça, um forasteiro que chega do interior do Estado torna-se, de imediato, presa do Vampiro de Curitiba. Os diálogos e situaçōes são mais violentos e sem disfarces do que nas peças anteriormente referidas. $O$ palavrão e a crueldade afloram no texto, identificando um tempo decididamente mais agressivo e cruel. Boêmio, Ladrão, Drogado, Prostituta, Vampiro, falsos pastores e profetas constituem algumas das personagens que compõem a geografia humana do submundo da cidade. Nenhuma piedade ou idealização se manifestam na justaposição de cenas destinadas a descrever Curitiba e seus moradores. A estrutura dramática frouxa e desigual não permite, contudo, que sobreviva teatralmente este texto, confuso e superficial.

14 CARDOSO, Geraldo Magela. Curitiba, capital do freezer. Curitiba, 1992. Mimeog. 
Comemorando os 300 anos de fundação da cidade, Enéas Lour e Mário Schoemberg escrevem Trecentina (1993), uma paródia criativa sobre a história da fundação da cidade, somando personagens da commedia dell'arte Arlecchino - dos folhetins românticos - Scaramouche - com figuras históricas do passado e da atualidade. Texto criativo e muito hilariante, cativou de tal forma os públicos que voltou em edições posteriores, mantendo a mesma dupla de heróis picarescos em aventuras diferentes, em Trecentina 2 (1995) e Trecentina 3 (1996). Os enredos mantiveram a perspectiva da sátira política e comportamental. Em torno de pares apaixonados, Arlecchino e Scaramouche improvisavam cenas impagáveis, construídas para fazer rir. As anedotas envolviam sempre a realidade do momento, não poupando a ridicularização de pessoas reais com alguma projeção social.

Neste final do século XX, em que a efemeridade tornou-se um dos valores mais característicos, o que pensar de um espetáculo como $O$ vampiro e a polaquinha,$^{15}$ estreado em 1992, com mais de cinco anos em cartaz? A interrupção havida em 1994 não impediu que ao retornar reencontrasse espectadores e aplausos.

A história do teatro na cidade raras vezes registrou temporadas que ultrapassassem um ano com público. Esta excepcionalidade merece uma reflexão acerca das razões que justifiquem a Curitiba teatral que deu certo.

Dirão os céticos e mal-humorados que há duas razões: o teatro Novelas Curitibanas comporta poucos espectadores, por isso é fácil mantê-lo com público; ou então, o sexo de algumas cenas da peça é chamariz mais do que suficiente para que leigos e carentes ocupem as cadeiras do teatro. Dirão os mais sisudos: a peça continua em cartaz porque as pessoas são atraídas pelo nome e fama de Dalton Trevisan. Os conhecedores do meio teatral assim poderiam explicar o sucesso: o elenco é homogêneo, o ritmo da peça está bem dosado, o texto equilibra o cômico e trágico com mão de artista, a direção soube trabalhar com a variedade e a escrita característica do autor etc. etc.

Todas essas explicações são plausíveis. Cada uma em sua circunstância. Outros ângulos surgem, todavia, e que solicitam argumentos mais densos como resposta.

O que representa para o teatro a encenação dos contos de Dalton Trevisan?

Em primeiro lugar, a dimensão histórica. Em 1. de junho de 1957, estreou $A$ volta do filho pródigo, encenação de conto homônimo de Dalton

15 TREVISAN, Dalton. $O$ vampiro e a polaquinha. Curitiba, 1992. Mimeog. 
Trevisan, dirigido por Glauco Flores de Sá Brito para o Teatro Experimental Guaíra. A Associação Paranaense de Críticos Teatrais - APCT - lhe conferiu o prêmio de melhor texto para o teatro naquele ano. Em 1990, Ademar Guerra, seguindo sugestão de Constantino Viaro, se interessou por levar ao palco um texto de Trevisan. $O$ contista, segundo a imprensa, teria aceito escrever uma peça teatral especialmente para a oportunidade. Algum tempo depois, porém, Ademar Guerra recebeu delegação do autor para escolher ele mesmo os contos que comporiam a peça-antologia Os mistérios de Curitiba, encenada em 1990. Trevisan acompanhou os ensaios. $O$ vampiro e a polaquinha (1992) passou pelo mesmo processo: o diretor selecionou e ordenou os textos do contista, sem alterá-los.

As cenas possuem alta voltagem dramática, o diálogo busca a coloquialidade da fala natural (fundamental para a naturalidade da dicção do ator), as personagens ganham densidade psicológica e física, até mesmo pela repetição - característica estética da obra de Trevisan -, o ritmo das cenas tem a velocidade do tempo rápido do cinema e do teatro.

Há, em Os mistérios de Curitiba, um descompasso entre os fragmentos puramente "literários", isto é, narrativos - representados nos dois espetáculos por um narrador, quase sempre ocupando uma das laterais do palco - e a força dos diálogos. Nada mais justo: a narração é um processo literário de tempo passado e externo à ação, estranho à peça teatral, sempre presentificada, corporificada e atualizada no palco. Os dramas que se servem de narradores sempre estabeleceram rupturas rítmicas e espaciais que continuam criando descompassos e vazios nos espetáculos. Essa diferença de natureza das linguagens literária e teatral não impediu, contudo, que prevalecessem nos dois espetáculos - muito mais no segundo, que apresentou maior maturidade cênica - o humor das situações; a riqueza humana das personagens, via de regra degradadas; a contundência dos conflitos do ser humano ante a exposição e descoberta de seus anseios viscerais; a paixão mórbida do escritor pela Curitiba que o viaja, explícita na crítica feroz da balada "Em busca da Curitiba perdida", que fecha o espetáculo.

Embora correndo o risco de simplificar a diversidade do material dramatúrgico à nossa disposição, tentaremos agrupar as diferentes peças, tomando como angulação preferencial a presença explícita de Curitiba e a perspectiva adotada pelo dramaturgo para olhar a cidade. 


\section{SÉRIE PITORESCO-UFANISTA}

\subsection{Histórica}

- Minha cidade sem portas

- Terra de todas as gentes

- Ó Curitiba, nossa tribo, salve! salve!

- Os trancetês do CPT

1.2 Doméstica

- $O$ vigilado

- Castor e Pólux

- Marumby

\section{SÉRIE CRÍTICA}

2.1 Histórico-política

- Maria Bueno

- Funeral da Rua 37

- Esmeralda Bandeira

- Gilda da Boca Maldita

2.2 Social e espacial

- Revistas teatrais

- Flor do campo

- Coisas da moda

- Curitiba velha de guerra

- Dos seios desta mãe gentil

- Rua das Flores não é mais aquela

- A reputação do Quatro Bicos

- Curitiba, capital do freezer

- a série Trecentina

2.3 Universalizante

- O Homo sensualis

- Místérios de Curitiba

- $O$ vampiro e a polaquinha

Predomina no primeiro grupo de peças (item 1.1) a intenção de manter no horizonte próximo do espetáculo os acontecimentos que construíram a his- 
tória da cidade ao longo dos anos. Nesses textos a leitura se faz sempre pela submissão do teatral ao factual. São peças que se destinam a construir uma imagem para usufruto da cidade: elas ensinam, divertem e elogiam.

No segundo grupo (item 1.2) encontramos a Curitiba dos cartões-postais, a cidade imaculada que os dramaturgos constroem à revelia da realidade. Moldura indispensável para valorizar um quadro que sobreviveria, entretanto, sem ela. Essa Curitiba se sustenta exclusivamente na intenção ufanista do dramaturgo, apreciada num viés superlativo que não se respalda na realidade.

Em alguns textos (item 2.1) a história é construída por indivíduos: heróis por vezes anônimos de uma cidade que os esquece, embora sentida como palpitante e conflituosa. $O$ palco se transforma em tribuna para a exposição e defesa dos oprimidos. A necessidade de heróis - triste povo que os necessita, lembrando Brecht - elege personagens e lhes dá destaque. Antes símbolos de luta do que seres individualizados, geograficamente limitados, esses protagonistas portam bandeiras de idcais e valores revolucionários. Os textos realizam recortes no tecido histórico e social, destacando conflitos que evocam lutas ideológicas marcantes.

O grupo mais numeroso e constante (item 2.2) abriga-se sob a intenção explícita de falar sobre a cidade a partir do caleidoscópio de tipos e espaços. Nessas peças predomina a perspectiva crítica que desmistifica os estereótipos de uma cidade ordeira e pacífica. O olhar agudo do analista penetra nas contradições urbanas e traz à luz a denúncia de comportamentos e situações condenáveis. Sob o manto da comicidade esconde-se a nudez dos defeitos e dos vícios. Curitiba, mãe renegada por filhos ávidos de independência, se converte em ré de crimes de ambição, hipocrisia, solidão, desencontros e crueldade. Permanece, porém, uma ligação afetiva em algumas peças, como o filho pródigo à espera do aceno que o traga de volta à família, ao seio gentil, à velha de guerra, àquela rua paradisíaca do passado.

Tratando do homem histórico de forma alegórica e, portanto, multisignificativa, o conjunto de textos universalizantes (item 2.3) se permite fundir o tempo factual com a crítica e a análise de seus componentes essenciais. Desautomatiza a visão documental e referencial, buscando exprimir as faces múltiplas e mais interiores do homem urbano, devorado por sua própria ambição, medo e hipocrisia. O local, determinado por referências rápidas, tende a se esvair geograficamente, cedendo ao espaço interior a fala e o conflito. São curitibanas sim as personagens mas simultaneamente se evadem da cidade, passando a habitar outros centros urbanos, porque os valores que representam caminham com elas, sem âncoras espaciais. 
É possível concluir, tomando por base esse rol de peças, que a dramaturgia de assunto e cenário curitibanos evolui claramente de uma visão mitificadora e educativa para um enfoque crítico, por vezes destruidor e negativista. Cada uma dessas posições obedeceu a injunções de ordem histórica, circunstancial e ideológica que, em seu conjunto, permitem traçar uma evolução.

Ao longo dos anos, a constância no aparecimento de peças tratando de Curitiba nos faz acreditar que a cidade seja um motivo propulsor dos mais significativos para a criação dramatúrgica. Cumpre reconhecer que, se o teatro tem como uma de suas funções a de ser espelho de uma realidade, as peças aqui arroladas contribuem para desenhar uma imagem evolutiva e bem delineada da cidade e dos curitibanos. E a história da cidade acaba por se documentar também na história de sua dramaturgia.

\section{RESUMO}

O presente ensaio descreve algumas peças de dramaturgos paranaenses que tomaram a cidade de Curitiba como assunto e cenário. Mostra as características de vários textos dramáticos e as perspectivas com que apresentaram a cidade e seus habitantes. Estabelece também as relações de semelhança e diferença entre os textos, procurando apresentar razões de ordem histórica, cultural e social que ocasionaram essa variedade.

Palavras-chave: teatro em Curitiba, história do teatro brasileiro, dramaturgia.

\section{RESUME}

Cet essai décrit quelques pièces d'écrivains du Paraná qui ont pris la ville de Curitiba comme sujet et scène théatrâle. Il montre les characteristiques de beaucoup de textes dramatiques et les points de vue avec lesquels la ville et ses habitants se sont présentés. Il établit aussi des rélations de similitude et de différence entre les pièces, en cherchant les raisons d'ordre historique, culturelle et sociale qui ont fait surgir ces variétés.

Mots-clé: thêâtre à Curitiba, histoire du théâtre brésilien, dramaturgie. 


\section{REFERÊNCIASBIBLIOGRÁFICAS}

BRAZ, Castella. Coisas da moda: peça de costumes locais em 2 actos para ser lida. Curitiba: [s.n.], 1923.

CARDOSO, Geraldo Magela. Curitiba, capital do freezer. Curitiba, 1992. Mimeog.

CÓRDOVA, Nelson di. Gilda da Boca Maldita. Maldita Boca Maldita. Curitiba, [198?]. Mimeog.

COSTA, Marta Morais da. Teatro em papel jornal. São Paulo, 1987. Tese (Doutorado) - FFLCH, Universidade de São Paulo. p. 125-135.

GALERA, Marinho; VÍTOLA, Paulo. Ó Curitiba, nossa tribo, salve! salve! Curitiba, 1980. Mimeog.

GEMBA, Oraci. Maria Bueno. Curitiba: s.i.e.

GROFF, Luiz. A reputação do Quatro Bicos \& outras reputaçōes. São Paulo: Massao Ohno, 1986.

GRUPO TEATRAL PRISMA. Curitiba velha de guerra. Dos seios desta mãe gentil. Curitiba, 1980. Mimeog.

MUNHOZ, Alcides. Comedia Paranaense (l. ${ }^{a}$ série). Curitiba: [s.n.], 1921. p. 17-213.

ORTEGA, Laerte. Funeral da Rua 37. Curitiba, 1976. Esmeralda Bandeira. Curitiba, 1978. Mimeog.

PORTELA, Lineu. Rua das Flores não é mais aquela. Curitiba, 1986. Mimeog.

SANTOS, Benedito Nicolau dos. Marumby: opereta de costumes paranaenses em 3 atos. s.i.e.

TÁVORA, Adriano. Os trancetês do CPT. Curitiba, 1986. Mimeog.

TREVISAN, Dalton. O vampiro e a polaquinha. Curitiba, 1992. Mimeog. 